broadcast by the B.B.C., had nothing supernormal about it, being merely somewhat shallow and quite normal considering the muscular movements made by the medium during the trance. Thus the report as a whole contains no good evidence that Rudi Schneider possesses supernormal powers ; and further controversy concerning the case can therefore be post. poned until positive evidence is adduced based upon the kind of instrumental methods outlined in the present report.

\section{National Institute of Industrial Psychology}

THE annual report of the National Institute of Industrial Psychology appears in the Human Factor, vol. 8 , No. 12. The Institute is approaching a critjcal period in its career, when lack of funds may seriously curtail its research work. The report stresses this fact, and describes the work accomplished along various lines, touching on investigations in factories, warehouses, offices and shops, investigations of the processes of distribution, vocational guidance, research and educational work. A vocational guidance scheme has been launched in Bristol; and largescale experiments in Fife, and in Borstal institutions, have been completed this year. Researches into the possibility of simplifying and modifying tests of manual skill, and of devising tests for mathematical and linguistic ability, and the part played by rhythm in manual work are being continued. A study of the use of practical performance tests of intelligence and, on the vocational selection side, the analysis of three occupations, namely secretarial work, nursing and secondary school teaching, have been completed.

\section{Liverpool Geological Society}

THE seventy-fifth anniversary of the foundation of the Liverpool Geological Society was marked by a scientific conversazione, under the presidency of Dr. R. G. Wills, held in the Department of Geology, of the University of Liverpool, on December 11. The assembly commenced with the reading of the minutes of the first ordinary meeting of the Society in 1859, after which the Society's Medal was presented to Mr. Emil Montag, Swiss consul in Liverpool, for services rendered to the Society during his twentyfour years' active membership, his editorship, his contributions to British and Swiss geology and his work in providing facilities for study in Switzerland. Prof. H. H. Read, Herdman professor of geology in the University of Liverpool, vice-president of the Society, then delivered a short lecture on earthquakes, followed by a demonstration of the University seismograph. Dr. E. Neaverson lectured on palæontological exhibits, and there was a demonstration of rockcutting and of new maps. Amongst the exhibits on view at the conversazione was an interesting collection of fossils, new instruments and minerals, the latter including specimens of two new British minerals recently found in Scotland; chondrodite, found in association with metamorphic limestone, and stichite, found in association with ultra-basic rocks.

THE Liverpool Geological Society, which publishes an annual Proceedings, has mado many valuable contributions to geological history, and among its most distinguished members in the past were George H. Morton, one of its founders, and author of the "Geology of the Country Around Liverpool" (1863). After the Geological Survey had examined the area, a second edition of Morton's work was issued in 1891. The Rev. H. H. Higgins made valuable discoveries of fossil ferns in the Ravenshead railway cutting near Rainhill in 1870, and H. C. Beasley described the well-known labyrinthodont footprints from Storeton quarries, Cheshire, which G. H. Morton later named Cheirotherium stortonense. Despite what may be called a geological and palæontological poverty amongst the rocks of its sandstone area, the Liverpool Geological Society has kept research well to the fore in its history, and its Proceedings contain many valuable contributions to geological science.

\section{Apparatus for Photographic Reproduction}

THE reproduction of documents, drawings, etc., by photography is, of course, widely practised. It is possible by direct photographic printing to do such work without a camera. With sheets of translucent material of which only one side is used for the design or writing, such a method is capable of furnishing a paper negative which may be used for printing positive copies. The same method may be used for making readable copies which are negatives only in respect of black and white. If, however, the sheets of the original have matter on both sides, this simple method of printing is not possible, and it is necessary to use the method of 'reflex' photographic printing to make a negative, from which positive copies are made by printing through. Reflex printing consists in placing a sheet of the sensitive paper in contact with the matter to be copied, and exposing through the sensitive paper. Differential reflection from the design and its background is sufficient to give a printable image. These methods have long been known and used for the reproduction of copies of the same size as the originals. A very convenient portable apparatus comprising lamps, printing frame and automatic exposure timing device, which we have examined, has now been placed on the market by Messrs. Bornett and Co., Ltd., 7-8 Idol Lane, E.C.3. This apparatus is known as the "Rectophot Rapid Reproducer" and is made in two sizes, the smaller of which will deal with papers $13 \frac{1}{2}$ in. $\times 10$ in. ; the larger with 22 in. $\times 15$ in.

\section{Synthetic Compound with Vitamin $\mathbf{B}_{\mathbf{2}}$ Activity}

As is well known, lactoflavin induces growth in rats fed on a vitamin $\mathrm{B}_{\mathbf{g}}$ free diet. In a lecture at the Kaiser Wilhelm Institute for Medical Research in Heidelberg, Richard Kuhn, who with P. György discovered the biological activity of lactoflavin, reported that he had synthesised a compound with the same properties as lactoflavin. The synthetic substance was prepared by interaction of a suitable derivative of 1-nitro-3, 4-xylol with $l$-arabinamin, with subsequent reduction of the product formed and condensation with alloxan. $0.015 \mathrm{mgm}$. of this substance prevented hypovitaminosis in rats. This dose is of the same order of magnitude as that required for lactoflavin, whereas the corresponding 
synthetic substance without the two methyl groups on the benzene ring was completely inactive in this dose. The synthetic substance combines with the protein of the 'yellow ferment' of Warburg, prepared according to the method of Theorell, yielding a catalytically active compound, thus behaving exactly like lactoflavin. The optical rotation in alkaline solution of the two substances is the same. In order to decide definitely whether the two compounds are identical in every respect, Kuhn intends to prepare compounds containing the ribose and xylose radical, instead of arabinose, for comparison.

\section{Irrigation in India}

THe report on "Irrigation in India in 1931-32" (Delhi : Department of Industries and Labour) shows that the total irrigated area in British India in that year fell slightly below thirty million acres, of which more than half was in the Punjab and the Madras Presidency. In the whole area, the figures represent slightly more than 12 per cent of the area sown, rising to 34 per cent in the Punjab and 93 per cent in Sind. Among the largest new irrigation works in progress is the construction of a dam at Mettur on the Cauvery to store flood waters. About half this work was completed by the end of the year. The works in connexion with the new Lloyd barrage at Sukkur in Sind are approaching completion.

\section{Research in Dairying}

THE annual report for 1933 of the National Institute for Research in Dairying, University of Reading, contains a summary of the work done during the year in the various departments, and brief abstracts of papers published from the Institute. Reference is made to the death of the first director, Dr. Stenhouse Williams, in whose memory a new library building has been erected. Attention is also directed to the financial stringency from which the Institute is suffering, and which will necessitate the abandonment of valuable work now being conducted in the Physiology Department and the Nutritional Laboratory unless additional funds are forthcoming within the next few months.

\section{Exhibition of Architecture}

AN exhibition of an interesting character has recently been opened at the new premises of the Royal Institute of British Architects, 66 Portland Place, London, W.1. Here is to be seen a collection of more than 1,200 large photographs of buildings and many models showing recent developments in architecture throughout the world. It has taken two years to bring together this international collection, which is well displayed and is divided into subjects such as public buildings, hospitals, schools, houses, which enables the visitor to compare the designs of leading architects in different countries side by side in a manner which is seldom possible. The exhibition does not deal with planning or construction, but for those interested in these matters there are a few sets of drawings and particulars showing all the stages through which a project must pass before a building can reach completion; the extent of this detailed work will probably be a surprise to the layman. The exhibition is open to the public without charge from 10 to 6 until January 5 .

\section{American Association for the Advancement of Science}

THE ninety-fifth meeting of the American Association for the Advancement of Science will be held at Pittsburgh commencing on December 27. On December 31, the retiring president, Dr. Henry Norris Russell, will deliver an address entitled "The Atmospheres of the Planets". Among the general addresses to be delivered are: Prof. E. A. Horton, "Homo sapiens, Whence and Whither"; Prof. Arthur B. Lamb, "Crystallogenetic Adsorbents"; Dr. A. Franklin Shull, "Weismann and Hæckel : One Hundred Years" ; Prof. H. H. Newman, "Twins reared apart and the Nature-Nurture Problem"; Dr. Mark H. Liddell, "The Auditory Spectrum". Prof. Albert Einstein will deliver the Josiah Willard Gibbs lecture of the American Mathematical Society on December 28. On December 30, there will be a symposium on the relation between science, especially scientific organisations and institutions, and the Press. Speakers will represent the universities, technical and medical schools, the National Association of Science Writers, Science Service, the Associated Press, the Hearst Service and representative newspapers. Further information about the meeting can be obtained from Dr. Henry B. Ward, American Association for the Advancement of Science, Smithsonian Institution Building, Washington, D.C.

\section{Announcements}

SIR IsIDORE SALMON, chairman and managing director of Messrs. J. Lyons and Co., Ltd., has been elected president of the Decimal Association, in succession to Lord Hirst.

THE Karl Sudhoff medal has been awarded by the German Society of the History of Medicine, Natural Sciences and Technique to Prof. T. Györy, professor of the history of medicine in the University of Budapest.

THe annual meeting in 1935 of the British Medical Association will be held at Melbourne on September 11-13, under the presidency of Sir Richard Stawell, consulting physician to the Melbourne Hospital.

Applications are invited for the following appointments, on or before the dates mentioned:-A lecturer in electrical engineering at the North Staffordshire Technical College, Stoke-on-Trent-The Clerk to the Governors, Education Office, Town Hall, Hanley, Stoke-on-Trent (Dec. 31). An assistant in the Technological Department of tho Royal Scottish Museum, Edinburgh, 1-The Director (Jan. 12). A principal of the Northern Counties' Training College of Cookery and Domestic Science, Newcastleupon-Tyne-The Secretary (Jan. 14). An assistant in natural history in the University of AberdeenThe Secretary (Jan. 20). A Dunville professor of physiology and a J. C. White professor of biochemistry in the Queen's University of BelfastThe Secretary (Feb. 28). A chemist in the Admiralty Chemical Pool-The Secretary of the Admiralty (C.E. Branch), Whitehall, London, S.W.1. 